\title{
ADEQUACY OF GEOTEXTILE TUBE DEWATERING IN THREE RIVER REMEDIATION SCENARIOS
}

\author{
GERBEN VAN DEN BERG ${ }^{1} \&$ FILINTO ALEXANDRE PINTO DE OLIVEIRA $^{2}$ \\ ${ }^{1}$ TenCate Geosynthetics Netherlands B.V., The Netherlands \\ ${ }^{2}$ Geosin, LDA, Portugal
}

\begin{abstract}
Natural processes and human interference can lead to undesirable sedimentation of a magnitude difficult to deal with in an economical, ecological and societally acceptable manner. Showcasing various examples throughout the world, criteria to choose an adequate river remediation technology will be discussed, in three distinct scenarios: (1) the case of natural processes leading to a build-up of contaminated sediments; (2) the case of industrial activity leading to contamination; and finally (3) the case of disaster management. For the first time we will discuss the approach taken in Portugal to clean the Tago river at Vila Velha do Rodão where a layer of sediment with high cellulose levels covering the bottom on both sides of the Porta de Rodão at the heart of the Natura 2000 Site and UNESCO World Heritage listed natural park had to be removed and dewatered. Other cases of river remediation projects will be presented as well, such as the case of Fox river (USA) and Zutphen (the Netherlands), where contaminated sediments were used to rebuild the entrance of a river port. We will also touch upon the potential for tube dewatering technology as a response during disaster management and the hurdles encountered in the actions around two red mud disasters. The first dating from 2010 in Hungary at Ajka where a dam breach in a containment facility released $1.1 \mathrm{Mm}^{3}$ of red sludge into a widespread area, polluting agricultural land and water ways. The second at the Rio Doce at Vale Samarco in Brazil in 2015, where dewatering bags were used to build a dam using the red mud spilled into the river.

Keywords: tube dewatering, contaminated sediments, remediation, TenCate Geotube ${ }^{\circledR}$, sediment use.
\end{abstract}

\section{INTRODUCTION}

Although sediment load management in rivers can reduce erosion and sediment settlement at inappropriate places, maintenance dredging remains an indispensable tool in keeping the desired functionality of a river intact. When sediment mixes with industrial or municipal waste streams, the approach taken increases in complexity, cost and often duration. Questions like problem ownership and project funding assume a political edge due to the effects of contaminants on human health, flora and fauna. Decision-taking processes take longer with the increased need to investigate the gravity of the problem, the best way to remediate, and the effects of the remediation itself on public health, flora and fauna, as well on the public opinion. With increasing awareness of the need for a clean environment and to streamline these processes, legislation, rules and best-practice guidelines have been developed in the past years by waterbodies, dredging associations, and environmental policy makers on regional, national and international levels.

Now that dumping at sea of contaminated sludges is forbidden in Europe, alternative solutions are even more needed especially in deltas and near ports where most river sediments end up. Landfill potential is limited and expensive, so that alternatives for dumping are actively studied and practiced (Gregoire [1]). Although primary construction material is scarce in many areas, dredged sediment is considered to be waste and to fall under the waste directive of the EU. For reasons of scale, durable "local" treatment alternatives are easier to envisage close to a port than along a river since treatment can be organised economically and on a larger scale in the vicinity of the port, such as the facilities created in Antwerp, Hamburg and close to Rotterdam. River-sediment deposits may be wider spread and are often more 
unpredictable in volume. Regulations surrounding land and upland dewatering sites are very restrictive, particularly for land that is near streams, rivers and lakes. For the same reasons, finding appropriate re-use possibilities seems even more difficult.

Taking a holistic approach and on the basis of several examples of realized projects at different places in the world, this paper discusses decision criteria for the use of geotextiletube dewatering technology in three distinct scenarios: the case of natural processes leading to a build-up of contaminated sediments, the case of industrial activity leading to contamination and finally the case of disaster management.

\section{GEOTEXTILE-TUBE DEWATERING}

Tube dewatering technology helps in the de-silting waterways in a very effective way. Simultaneous to the dredging operation, the dredged volumes are massively reduced by separating liquids from solids and contaminants. In the final stage the consolidated contaminated solids are either transported off-site or are left in place and capped such that an in-situ landfill is created. Depending on the degree of contamination the land can then be reused for appropriate purposes. On land, but also semi-submerged, tubes have been used for land reclamation, the creation of sedimentation areas, shore-line refurbishment and current diversion.

Tube dewatering technology consists of various successive phases in volumes that are determined mainly by the capacity of the dredge. Sludge is pumped up and introduced directly into large, permeable geosynthetic containers in which solid-liquid separation takes place. Very often polyelectrolytes are used to accelerate the separation and to fully use of the permeability of the geotextile fabric. Some fabrics achieve a permeability of up to $18 \mathrm{~m}^{3} / \mathrm{m}^{2} / \mathrm{min}$. From the moment pumping starts, the water drains through the pores of the containers while the particles are retained. The proper addition of polyelectrolyte and the correct choice of fabric lead to high particle-retention rates of up to $99 \%$ of even the finest particles below 63 microns. By adsorption, undissolved contaminants like heavy metals will at the same time be retained effectively. After the fill stage, the geotextile containers are left to drain for an optimum result. For sandy sludges this may take a day or so, for silts and clays it can be a matter of weeks. The containers can then be removed, at a time convenient to the contractor, or they can be used as an integral part of a structure of a geotechnical nature, like the foundation of a parking lot or a park lawn.

\section{TO USE OR NOT TO USE, THAT IS THE QUESTION}

To determine if such a tube application is possible or not, criteria are defined on a case-tocase basis. Apart from the obvious budgetary constraints and legislative boundaries, geotechnical and technical questions need to be answered satisfactorily. These technical questions concern the quantity of material available, the characteristics of the material, the type of equipment needed, and the time and space limitations that are given to realize the project with sediment. In most cases potential sediment use will be weighed against other options. So a strong case needs to be made.

Prior to the use of sediments in a construction it should be clear what the purpose of the construction will be, and whether the contamination will contribute to, or limit, the functionality and the life expectancy of that construction. The demands on the construction and the materials used should be defined, as well as the way it can be built and with which selection of materials.

Potential sediment uses are dependent on the sediment characteristics (mean diameter, organic matter content, shear strength, density, Atterberg limits, etc.) and linked to the ecological and toxicological acceptability locally as well as the economic benefits that can 
be found close to its source for products or features made using the sediments. Beneficial use of dredged material based on scientific knowledge can be more practical, cost effective and environmentally advantageous when integrated with watershed-planning processes and regional strategies for managing sediment resources (Oliveira [2]).

In many applications where sediments are used, such as for agricultural topsoil, land creation, bricks and pavements, dikes and berms, contamination, storage, handling and low shear strength are issues to be tackled. To overcome low shear strength, cement or other fill material may be incorporated in the dredged slurry for stabilisation purposes. Apart from the local availability and handling of large amounts of cement, stabilisation alone does not address the other issues, particularly storage of slurry prior to use. The ability of geotextile tubes to immediately dewater, store, contain and support dredged materials can address these problems for a variety of applications [...] (Howard et al. [3]).

Before dredging starts, it is necessary to know how much sludge is to be treated, how much dilution is necessary to make it pumpable, how long it will take to move the slurry and what is needed in terms of effort, time and space for dewatering to get to the stage of the intended use. Time and space are often the most basic requirements. Because filling and dewatering are continuous and occur simultaneously if the right fabric is chosen, the project run-time can normally be shortened using environmental suction dredging in combination with tube dewatering technology. The reduction of volume obtained has a direct effect on the space requirements. Less space is needed when less water is stored. To reach this goal, good dredging and pumping practice, sampling and monitoring during the dewatering as well as the right choice of equipment, like the right choice of fabric, polymer, shutters and pumps, help to avoid costly mistakes.

\section{THE TUBE}

The choice for a specific fabric and a specific tube configuration will determine to a large extent the effective water release and particle retention. The latter is an important criterion since contaminant retention depends to a large extent on the retention of particles below 60 $\mu \mathrm{m}$. In the absence of tests for large-scale sludge filtration, standard geotextile test methods are used, the results of which do not always reflect the real situation. There is for instance no test for clogging. Thus, despite equal (clear) water permeability according to EN ISO 11058 and a comparable 090 opening size, a tape-tape fabric will still clog faster in a dredging environment than a tape-monofilament fabric that achieves similar test results. To reduce the tensile forces on a plugged tube, several tape-tape fabric suppliers advise releasing the water by opening an unused fill port. It goes without saying that particle retention, especially of the finest (potentially contaminant-holding) particles is than no longer guaranteed, so that recontamination can take place. For this reason tape-tape fabric should be excluded on contaminated remediation sites.

Another misused geotextile criterion is tensile strength. Seams being the weakest part of a tube, seam strength, as an indicator of the overall strength of a tube, is more important than the tensile strength of the fabric itself.

Proper dimensioning of the bags, based on tests performed prior to the works, helps in getting the maximum amount of water out while effectively retaining fine particles. It also contributes to the continuity of the dredging operation and shortens the project run time, just as the correct choice of fabric, the correct flocculant dosing and the most appropriate layout will also do. Under-dimensioned tubes will potentially lead to turbulence inside the bag, to flocs breaking down and the fabric clogging, with poor dewatering as a result. Overdimensioning on the other hand may potentially lead to uneven filling of the tube, excessively slow filling, and to failure to raise the tube to the maximum fill height. As demonstrated by 
Stephens [4] correct but simple testing of the right fabric, accelerant and sludge combination before the design stage can help to prevent these problems and enables proper dimensioning of the hydraulics, the bags and the site.

\section{THE SITE}

Indeed the dimensions of a site can be determined on the basis of the quantity of sludge that is to be treated, the amount and characteristics of the dry solids in that sludge, and the available project run-time. The exact dimensions of a site can then be reduced by taking into account the hourly and daily capacity of the dredge, the capacity of the flocculant dosing unit, the required consolidation time per fill cycle, and the stacking potential of the consolidated tubes. If stacking is possible the dewatering can take place on a much smaller footprint.

For stacking, the tube content needs to have sufficient bearing capacity, as should the subsoil on which the tubes are laid out. Lawson [5] identified six external and four internal stability modes; local instability, geotextile bag rupture, erosion of fill through the geotextile bag and deformation of the contained fill. Zhu [6] divided the local instability into sliding, bearing failure, foundation settlement and slope movement. Fig. 1 shows these four geotechnical failure states potentially endangering a dewatering platform with an additional particular form of local instability that results from the fact that tubes are not sufficiently close to one another; V-notch deformation. This causes over-tensioning of the fabric of the upper tube when it slides into an oversized gap between two tubes below. Irregular consolidation, which can be caused by poor dewatering of the fabric, or varying settlement characteristics and bearing capacities of different fill materials in the same bag, has a similar effect to erosion of fill through the geotextile bag, but leaves an uneven base which can cause great stability problems for subsequent layers.
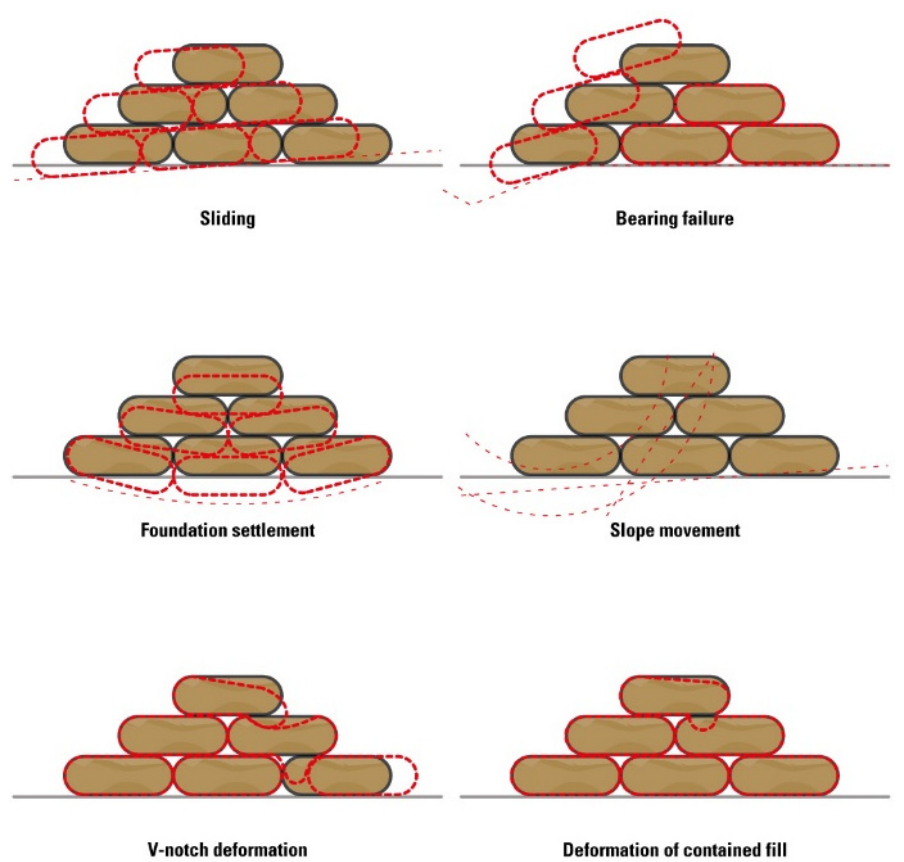

Figure 1: Failure states to avoid on dewatering platforms. 
Once the sludge and sediment characteristics are known, pumping cycles determined, tubes dimensioned and space requirements set, construction and clearing of the dewatering site should also be taken into consideration in the design stages. Access to the tubes, stability of roads, and transport distances to potential landfills influence the total project run time, but also have financial consequences that can influence the decision for or against re-use.

Now that we have discussed general technical and geotechnical criteria, we will show in the case studies how other criteria also play a role and interact with each other. The fact for instance that tube dewatering technology provides dewatering and consolidation simultaneously, reduces cost. Further cost reduction is obtained through reduced installation cost, reduced material transport, carbon footprint, equipment mobilisation, operation and dismantling cost. These benefits increase when the tubes enable use of the sediments.

\section{ZUTPHEN}

Zutphen is a clear case of erosion of a riverside caused by wave action created by ships entering the port. The solids sedimented just meters from the shore line.

The city of Zutphen in The Netherlands is located on River IJssel, a tributary of River Rhine. The old industrial harbour De Mars was refurbished as part of a restoration plan for the entire industrial area. The refurbished port would have to be able to accommodate ships with a draught of 2.8 meters, but the actual situation was that the silting of the entrance of the port led to smaller ships running aground in front of the harbour at low tide. Dredging the entrance to the original depth was clearly required. At the same time the riverbank needed to be restored to prevent silting in a few years after the termination of the works.

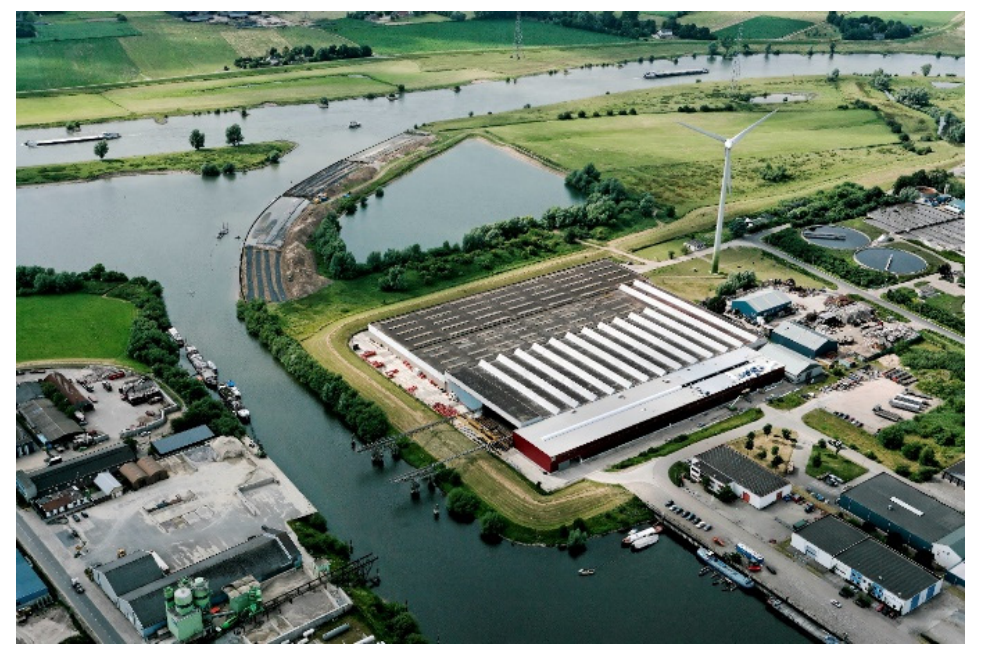

Figure 2: The entrance of the port with TenCate Geotube ${ }^{\circledR}$ units installed.

Bathymetrical studies and sediment analyses showed that a total of $6,000 \mathrm{~m}^{3}$ of Class 2 sediment and 12,000 $\mathrm{m}^{3}$ of Class 3 contaminated sediment had to be dredged. The Class 3 contaminated sediment would have required placement in confined disposal facilities.

For the restoration of the riverbanks, new building materials would have to be brought in to raise the level of the embankments and to protect against waves at high water levels. The TenCate Geotube ${ }^{\circledR}$ dewatering solution solved both problems in an economical and environmentally friendly manner. 
Stretching out along the $400 \mathrm{~m}$ riverbank that had to be restored, four sheet-pile compartments each $100 \mathrm{~m}$ wide were erected. The sheet piles delimited the dewatering platform from the River Ijssel. Not only they would give protection in case of rising water levels, but each adjacent basin could potentially serve as a temporary storage area in which the effluent water from the tubes could first be checked before being discharged into the river. In fact the opening in the sheet-pile construction through which the effluent water ran back freely into the river never needed to be closed, since at no point during the works did the quality of the effluent exceed the limits defined by the Ministry of Transport, Public Work and Water Management.

Each compartment held 4 tubes sized in relation to the sludge dewatering mass balance and the total surface area. With a volume of $400 \mathrm{~m}^{3} / \mathrm{h}$ at a $10 \%$ solids concentration, the environmental dredge filled two tubes at a time. Due to the accurate in-line dosing of chemical polyelectrolytes, the dry solids content of the material in the tube reached $65 \%$ within four days. After all the material had consolidated and dredging was finished the tubes were covered with a soil backfill.

The local authorities and the ministry can look back on a successful project that cost them only $70 \%$ of the cost using conventional construction methods. The harbour and its entrance were successfully dredged and the riverbank was restored with the use of local sediments.

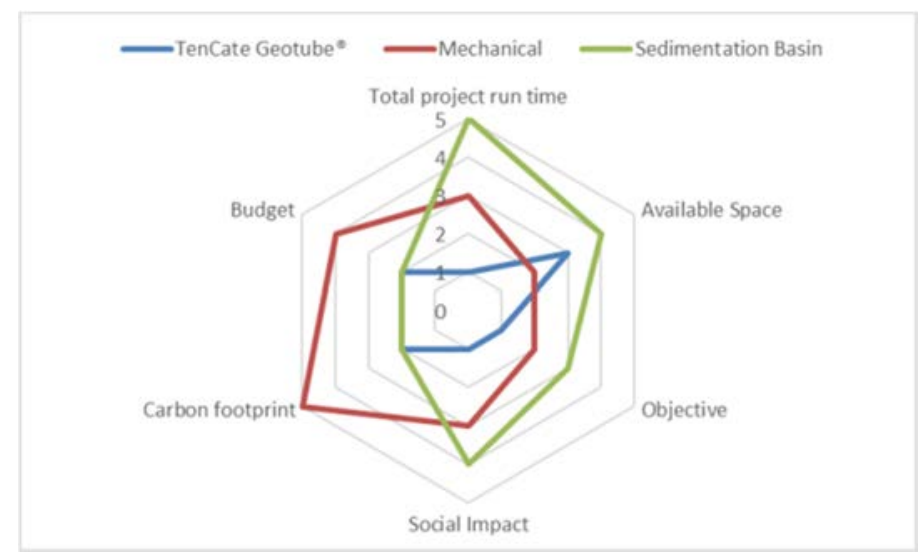

Figure 3: Chart comparing geotextile tube dewatering, mechanical dewatering and sedimentation basins on 6 criteria in relationship to the Zutphen project.

Re-use of contaminated sludge as a construction material has become inevitable. The Dutch Decree Soil Quality pragmatically integrates all aspects from dredging to application of soils and sludge, and favours local decision making based on risk assessment whereby the quality of the sludge mixture is regarded in relation to the function of the area it will be applied in and the development of the area as a whole. The potential risks of local standards are calculated on the basis of the soil function, along with an estimate of the degree of exposure (high, low average or contact with the soil or crop consumption of the soil) and the desired degree of protection of people, ecology and agriculture. The decree provides the generic norms, but local authorities can deviate from those norms as long as they stick within the stipulated framework. The decree contributes to a more positive way in which sludge is perceived; one no longer talks about slightly polluted soil, but sludge suitable for the class A "residential area" function. 


\section{FOX RIVER}

In the state of Michigan, USA, it was primarily the major PCB-contamination by several paper mills which required intervention at the head of the lower Fox River in Northeast Wisconsin. PCB is a known carcinogen in animals and a probable carcinogen in humans. After many years of study, the funds became available, turning what had been up to then a political and financial issue into a technical issue. When tube dewatering tests showed that $99.7 \%$ to $99.9 \%$ of solids could be captured and the contaminants were retained inside the monofilament-tape fabric bag, tube dewatering was selected as the most economical process for the first part of the works.

To be able to extend the consolidation period to 45 days on average, stacking proved crucial. Here a combination technique was used with clarifiers in front of the tubes, to evacuate immediately most of the free water as well as debris larger than $1 / 8$ ", so that hoses would block and reduce the flow towards the tubes. This set up helped to reduce space even more than was already obtained by stacking the geotextile bags that were $18.3 \mathrm{~m}$ in circumference and up to $50 \mathrm{~m}$ long. To avoid overdosing, polymer dosing was based upon the bed density inside the thickener unit.

Table 1: Hanging bag test results showing the capture rate of suspended solids in time.

\begin{tabular}{|lcc|cc|}
\hline Hanging Bag Test & $\begin{array}{l}\text { Logon } \\
\text { Total Solids }\end{array}$ & No. 2 & Removal Ditch & \\
\hline Influent total aolids & $6.50 \%$ & & $14.70 \%$ & Removal \\
1 min filtrate suspended solids & $12.5 \mathrm{mg} \mathrm{L}$ & $99.80 \%$ & $178 \mathrm{mg} \mathrm{L}$ & $98.80 \%$ \\
10 min filtrate suspended solids & $14.0 \mathrm{mg} \mathrm{L}$ & $99.78 \%$ & $18 \mathrm{mg} \mathrm{L}$ & $99.87 \%$ \\
1 hour filtrate suspended solids & $5 \mathrm{mg} \mathrm{L}$ & $99.92 \%$ & $4.4 \mathrm{mg} \mathrm{L}$ & $99.97 \%$ \\
\hline Total Solids (after 10 days & $24.20 \%$ & & $35.30 \%$ & \\
\hline & & & \\
\hline Hanging Bag Test & West Ditch & & West Ditch & \\
Total Solids & & Removal & No polymer & Removal \\
\hline Influent total aolids & $12.10 \%$ & & $12.10 \%$ & \\
1 min filtrate suspended solids & $2752 \mathrm{mg} \mathrm{L}$ & $77.20 \%$ & $174 \mathrm{mg} \mathrm{L}$ & $99.56 \%$ \\
10 min filtrate suspended solids & $36 \mathrm{mg} \mathrm{L}$ & $99.70 \%$ & $0.9 \mathrm{mg} \mathrm{L}$ & $99.99 \%$ \\
1 hour filtrate suspended solids & $11 \mathrm{mg} \mathrm{L}$ & $99.91 \%$ & & \\
\hline Total Solids (after 10 days & $50.40 \%$ & & $52.80 \%$ & \\
\hline
\end{tabular}

Table 2: Test results showing contaminant concentrations with almost undetectable levels of PCBs traces in the effluent.

\begin{tabular}{|l|l|r|r|}
\hline Constituent & & $\begin{array}{r}\text { Concentration } \\
\text { range of sludge }\end{array}$ & $\begin{array}{r}\text { Concentration in TenCate } \\
\text { Geotube }{ }^{\circledR} \text { Effluent }\end{array}$ \\
\hline PAH compounds & $\mathrm{ug} / \mathrm{kg}$ & $1.500-49.000$ & Not detected $(1-5 \mathrm{ug} / \mathrm{L})$ \\
PCB's (total) & $\mathrm{ug} / \mathrm{kg}$ & $100.000-140.000$ & $0.14 \mathrm{ug} / \mathrm{L}$ \\
PCB's (total (with polymer) & $\mathrm{ug} / \mathrm{kg}$ & $100.000-140.000$ & Not detected $(0.1 \mathrm{ug} / \mathrm{L})$ \\
Cadmium & $\mathrm{mg} / \mathrm{kg}$ & $2.6-7.9$ & Not detected $(0.5 \mathrm{ug} / \mathrm{L})$ \\
Lead & $\mathrm{mg} / \mathrm{kg}$ & $512-495$ & $9.4 \mathrm{ug} / \mathrm{L}$ \\
Copper & $\mathrm{mg} / \mathrm{kg}$ & $326-343$ & Not detected (10 ug/L) \\
Arsenic & $\mathrm{mg} / \mathrm{kg}$ & $7.3-7.7$ & $5.5 \mathrm{ug} / \mathrm{L}$ \\
Mercury & $\mathrm{mg} / \mathrm{kg}$ & $3.8-18.4$ & $0.14 \mathrm{ug} / \mathrm{L}$ \\
Zinc & $\mathrm{mg} / \mathrm{kg}$ & $3.700-3.700$ & $13 \mathrm{ug} / \mathrm{L}$ \\
\hline
\end{tabular}




\section{TAGUS RIVER (RIO TEJO)}

Another example of a successful remediation project where geotextile tube dewatering provided the solution is found at Vila Velha do Rodão. The River Tagus suffered from eutrophication, a problem related to large amounts of cellulose and the presence of paper industry in this part of Portugal. A layer of sediment with excessively high organic levels covered the bottom on both sides of the Portas de Rodão site at the heart of the Natura 2000 Site and UNESCO World Heritage listed as natural area.

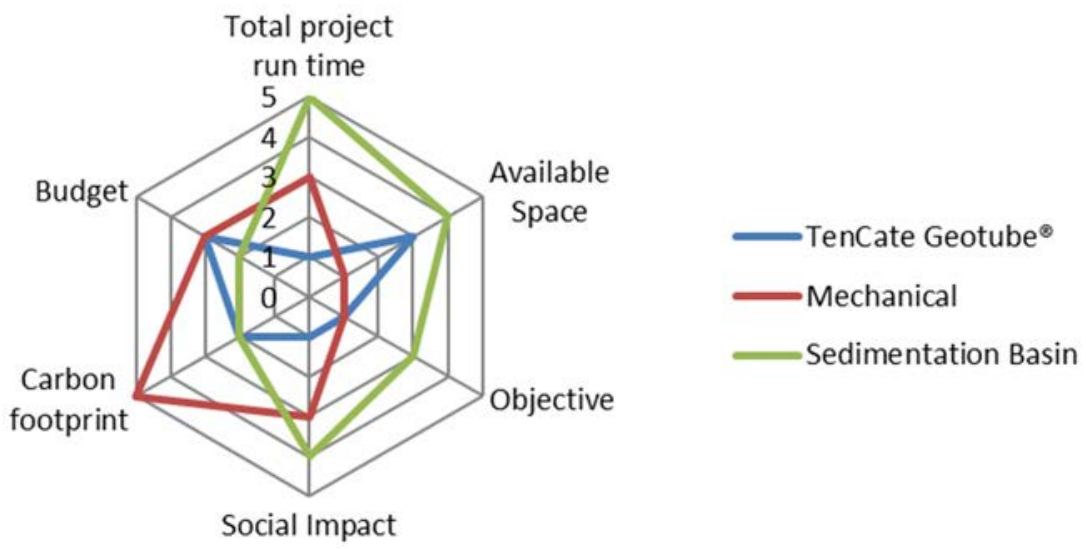

Figure 4: Chart comparing geotextile tube dewatering, mechanical dewatering and sedimentation basins on 6 criteria in relationship to the Portas de Rodão project.

Several dewatering treatment solutions were studied and tube dewatering technology finally came out best. Other solutions such as decantation basins required a lot of space and time. Also for reasons of impracticalities at the operational level as well as on social impact, decantation basins were discarded. At the other end of the spectrum, mechanical technologies were not preferred either. To mechanically treat such a large amount of sludge on an hourly basis would require powerful machines, or several of these. In addition it would require the construction of a monitoring basin for quality assurance. And finally, from a budget standpoint, either the cost had to go up in order to keep the total project run time reasonable, or the project would last longer than the tube dewatering solution for a similar budget. Geotextile tube dewatering was chosen over other methods for its rapidity, unlimited capacity of flow reception, adaptability and low carbon footprint.

As part of the solution to remediate and improve the ecosystem, the cellulose-holding sediments were hoovered in with a suction dredge operated by an experienced team of Portuguese divers. The pump used in this project was equipped with a sensor that allowed the height between the hose and the bottom of the river to be regulated. Several water jets disaggregated the sludge and kept the particles within the suction circle area. This was the most precise way of making sure that only sediment was removed while sand and rock remained in place. At the same time it allowed the slurry to be diluted sufficiently to achieve good flocculation later on in the process. All dredging equipment was mounted on a floating platform and monitored by professional divers. Once taken in, the slurry was pumped over $1.2 \mathrm{~km}$ to a temporary dewatering platform built by a consortium of highly specialized Portuguese companies. 
This platform consisted of $30,000 \mathrm{~m}^{2}$ open area adjacent to the river and still within the national park. This made the whole project rather sensitive and called for a state-of-the-art and safe dewatering platform. Because of this and the temporary nature of the facility, two separate $2.500 \mathrm{~m}^{2}$ basins were created on the site surrounded by drainage ditches. To avoid any contaminant leakage, the entire site was lined with a sandwich of a puncture-resistant nonwoven, a liner and a drainage layer. All materials came from the same supplier, which simplified their procurement and installation. For the same reason, the special membrane arrived on site fully welded, which also offered additional assurance on the quality of the joints.

A reception tank, initially required by the owner as a means of control over the flocculation, did in practice not add to the quality and even slowed down the operation, since it had to be cleaned out twice. From this tank, standing on a hill some 4 meters over the tubes, on average $225 \mathrm{~m}^{3} / \mathrm{hr}$ of flocculated sludge were gravity-fed into several of the eight connected tubes $(0.7$ bar $)$.

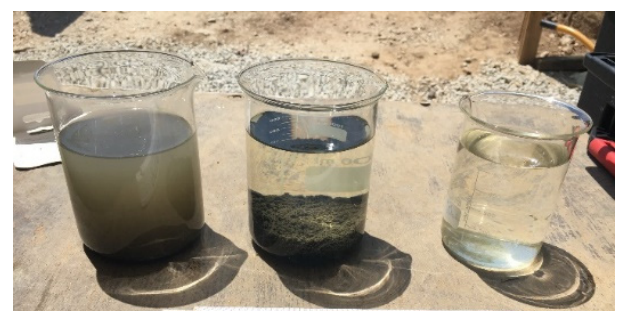

Figure 5: Influent, flocked influent, effluent.

As discussed, contaminant retention depends on the retention of particles below $60 \mu \mathrm{m}$. To achieve this, the choice of fabric as well as good flocculation is crucial. At the River Tagus the tube was made of a tape-monofilament fabric. The polymer was specially selected, prepared and dosed from a mobile unit sufficient to treat $12 \mathrm{~m}^{3} / \mathrm{hr}$ of solution. Dosage and concentration could be adapted to changes in the dry solids volume by touch screen. Due to the excellent water release and particle retention the effluent could be discharged directly into the river.

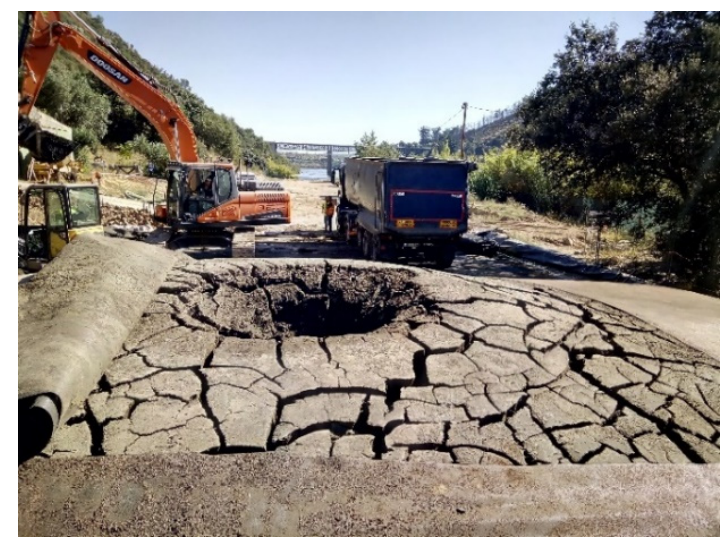

Figure 6: Removal of the dewatered bag content. 
Each TenCate Geotube ${ }^{\circledR}$ unit had a capacity of $367 \mathrm{~m}^{3}$. Over $90,000 \mathrm{~m} 3$ of slurry at $1,8 \%$ dry solids was treated this way. In just 1.5 months the goal of $40 \%$ average dry solids was reached and the tubes were removed, leaving the spot clear as if nothing had happened.

"Operação Tejo 2018" was the first public environmental remediation project in Portugal using tube dewatering. The extensive experience of contractors with this technology in other fields contributed largely to its success, as was recognized by the local community and national environmental authorities.

\section{AJKA AND RIO DOCE}

That local experience is key, is all the more true when it comes to rapid response management as we will briefly illustrate discussing the aftermath of the disasters in Ajka, Hungary in 2010 and the Bento Rodrigues dam disaster in Brazil five years later. In both cases an earth dam gave way, liberating millions of cubic meters of iron sludge from metal production. In both cases tube dewatering and consolidation technology could have been part of the solution. Red sludge can be dewatered large scale in tubes, and tubes can be turned into the cores of dams to redirect the flow, protect an area or to create new storage areas. In both cases a direct line was established at the highest level. In Hungary the absence of an experienced local partner proved to be critical and locally practiced solutions were pursued. In Brazil tube technology was used. Several designs were made to build a containment dam with tubes creating a sludge disposal area. Apart from issues like ease of access and communication, accurate mobilisation of means for testing to prove that a proposed solution will actually work, was crucial. Without proper testing, the effective use of tube technology is merely based on the experience of its installers. Experienced contractors know however, that without testing, the effectiveness of tube dewatering cannot be guaranteed. Thus experience should be one of the considerations when choosing for any technology, but certainly when opting for tube technology.

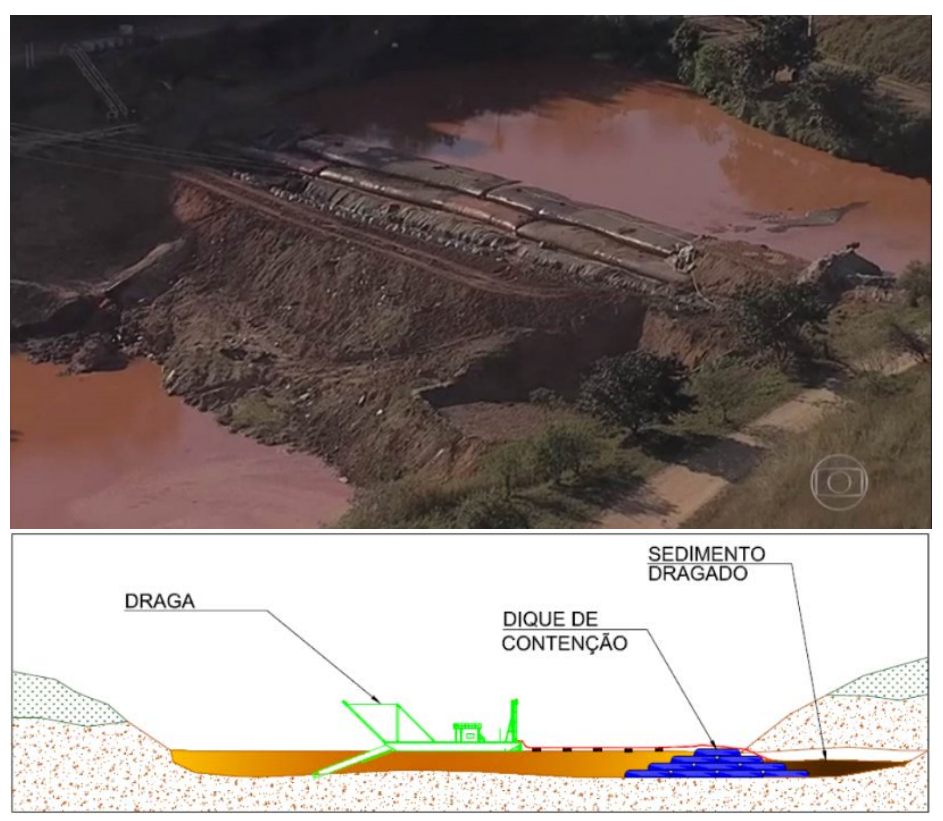

Figure 7: Picture and drawing of the tube dam. 


\section{CONCLUSION}

When evaluating the different possibilities to dewater sludge at least six main elements can be weighed in relationship to each other:

- objective;

- budget;

- carbon footprint;

- available space;

- social impact;

- total project run time.

When considering the use of sediments for building a structure, one should also look at:

- elementary questions of technical and geotechnical nature;

- the advantages and benefits of alternative or regular ways to build the construction;

- $\quad$ its purpose and the stability it should have;

- the right flocculant formula and dosage;

- the choice of the appropriate fabric;

- the most adequate dimensioning of the tube;

- $\quad$ good dredging practice;

- the interaction between the former three bullet points;

- local presence of the need for the solution;

- local presence of qualified installers.

We have demonstrated looking at the various cases how tube dewatering and containment can bring an answer to the question what to do with large quantities of contaminated sediments in river basins. In two of the cases present, Zutphen and Brazil, there was a need for a geotechnical structure locally and a possibility to use dredged sediments for that purpose. In such cases high social acceptability, low carbon footprint, savings made in transportation and by the reduction of the project run time, tube dewatering and consolidation is a valid choice.

\section{ACKNOWLEDGEMENTS}

I wish to acknowledge the help provided by Mr Tom Stephens and Mr Howard Murray.

\section{REFERENCES}

[1] Gregoire, P., Valoriser 300,000 $\mathrm{m}^{3}$ de sédiments de dragage en France? C'est possible! INTERSOL, International Conference on Soils Sediment and Water, Lille, 2014.

[2] Oliveira, E., Beneficial use of dredged material in agricultural land. 9th International SedNet Conference, Krakow, p. 54, 2015.

[3] Howard, I.L., Vahedifard, F., Williams, J. \& Timpson, C., Geotextile tubes and beneficial reuse of dredged soil: applications near ports and harbors. Proceedings of the Institution of Civil Engineers - Ground Improvement, 171, pp. 1-32, 2017. DOI: 10.1680/jgrim.17.00059.

[4] Stephens, T., Canal do Fundão contaminated sediments GDT analysis versus actual full scale project result. Geotechnical Special Edition 211 Geo-Frontiers 2011, Dallas, pp. 2131-2140, 2011.

[5] Lawson, C., Geotextile containment for hydraulic and environmental engineering. J. Geosynthetics International, 15(6), pp. 384-427, 2008.

[6] Zhu, M., Geotextile tube dewatering. Geostrata, pp. 26-32, 2015. 